\title{
Breves reflexões acerca da constitucionalidade dos decretos de prisões preventivas fundados na garantia da ordem pública
}

\author{
Caroline Carneiro Gusmão ${ }^{1}$
}

\begin{abstract}
Resumo: Este artigo tem como objetivo examinar a constitucionalidade do decreto de prisão preventiva fundado exclusivamente na garantia da ordem pública. Com o intuito de evidenciar o princípio da presunção de inocência como norteador do sistema processual penal brasileiro e, por consequência, a excepcionalidade da prisão preventiva, um tópico do artigo é dedicado à análise da não culpabilidade, do ônus probatório no processo penal e do in dubio pro reo; após, a pesquisa trata dos principais aspectos da prisão preventiva conforme o artigo 312 do Código de Processo Penal, com maior destaque para os decretos de custódia fundados na garantia da ordem pública. Por fim, a partir de uma interpretação conforme a Constituição, o artigo sustenta a inconstitucionalidade da custódia cautelar com fundamento exclusivo na garantia da ordem pública. A metodologia utilizada para o estudo foi a dogmática e o método de revisão, bibliográfico, consistente na técnica de análise de livros, teses e artigos científicos sobre as temáticas pesquisadas.
\end{abstract}

Palavras-chave: Presunção de Inocência. Prisão Preventiva. Ordem Pública. Excepcionalidade. Inconstitucionalidade.

\section{Brief reflections about the constitutionality of the pre-trial detention decree based on public order} warranty

Abstract: This paper aims to examine the pre-trial detention decree constitutionality based solely on the public order warranty. In order to show the presumption of innocence principle as a guide to the brazilian criminal procedural system and, consequently, the exceptionality of the pre-trial detention, a topic of the paper is dedicated to the non guilt analysis, the burden of proof in criminal proceedings and in dubio pro reo; after that, the research deal with the main aspects of the pre-trial prision according to article 312 of the Criminal Procedure Code, with greater proeminence to the custody decrees based on the public order guarantee. The used methodology to the study was the dogmatic one and the bibliographic method review, consistent with books, thesis and cientific paper analysis about the researched topics.

Key-words: Presumption of Innocence. Pre-trial detention. Public Order. Exceptionality. Unconstitutionality.

\footnotetext{
1 Caroline Carneiro Gusmão. Mestranda em Direito pelo Programa de Pós-Graduação Stricto Sensu do Centro Universitário Guanambi (UniFG). Graduada em Direito pela Universidade Estadual do Sudoeste da Bahia (UESB). Membro do SerTão - Núcleo Baiano de Direito e Literatura. Diretora de Mulheres da Lei do Capítulo Salvador da J. Reuben Clark Law Society (http://www.jrcls.org/). Advogada, inscrita na OAB/BA no 44.897. E-mail: ccgusmao1@gmail.com. http://lattes.cnpq.br/7319909866531304.
} 


\section{Introdução}

A vigente Constituição da República Federativa do Brasil (CRFB), com vistas a garantir a manutenção do estado democrático de direito (conjugação sócio-política em que a garantia das prerrogativas fundamentais do indivíduo se apresentam como a verdadeira razão de ser do Estado), normatizou o princípio da presunção de inocência ${ }^{2}$ em seu artigo $5^{\circ}$, inciso LVII (determinação de culpabilidade somente após o trânsito em julgado de sentença penal condenatória), a proibição de prisão salvo em flagrante delito ou por ordem judicial escrita e fundamentada (artigo $5^{\circ}$, inciso LXI) e a vedação à manutenção do cárcere em situações nas quais seja cabível a liberdade provisória com ou sem fiança (artigo $5^{\circ}$, inciso LXVI).

Embora sejam de observância obrigatória os princípios relacionados, a legislação pátria permite a decretação de prisões antes de prolação de decreto penal condenatório definitivo em situações excepcionais, descritas no artigo 312, caput do Código de Processo Penal (CPP). Referido artigo admite a custódia cautelar na modalidade preventiva quando houver prova da existência do crime, indício suficiente de autoria e necessidade da manutenção da garantia da ordem pública, da ordem econômica, da conveniência da instrução criminal, ou para assegurar a aplicação da lei penal.

O presente artigo visa examinar a conformidade constitucional dos decretos de prisão preventiva com fundamento exclusivo na garantia da ordem pública. Em linhas gerais, cumpre destacar que o conceito da expressão ordem pública, no direito brasileiro, é aberto, abstrato e, em regra, está relacionado com os termos clamor público, gravidade do delito, credibilidade das instituições, risco de reiteração da prática de condutas criminosas e necessidade de acautelamento do meio social.

A metodologia utilizada para o estudo foi a dogmática ${ }^{4}$ e o método de revisão bibliográfico, consistente na técnica de análise de livros, teses e artigos científicos sobre os seguintes temas: a) a presunção de inocência e seus desdobramentos à luz da atual Constituição

\footnotetext{
2 Sobre a presunção de inocência como sustentáculo do Estado Democrático de Direito, oportuno transcrever a reflexão de Luigi Ferrajoli: "a presunção de inocência não é apenas uma garantia de liberdade e de verdade, mas também uma garantia de segurança ou, se quisermos, de defesa social: da específica 'segurança' fornecida pelo Estado de direito e expressa pela confiança dos cidadãos na justiça, e daquela específica 'defesa' destes contra o arbítrio punitivo". (FERRAJOLI, Luigi. Direito e Razão - Teoria do Garantismo Penal. São Paulo: Editora Revista dos Tribunais, 2010, p. 506)

${ }^{3}$ É nesse sentido a manifestação do Ministro do Supremo Tribunal Federal, Ayres Britto, no julgamento do Habeas Corpus n. 111.244/SP, em 10/04/2012.

${ }^{4}$ Segundo Elaine Volpato (2017, p. 07), a metodologia dogmática, na área jurídica, tem por função "fornecer critérios para a produção do Direito e oferecer critérios hermenêuticos de sua aplicação, além de ordenar e de ajudar na sistematização do ordenamento jurídico"; trata-se, portanto de pesquisa de caráter teórico, com vistas a contribuir para futura análise de casos concretos.
} 
brasileira, e b) os aspectos autorizadores da decretação da prisão preventiva, em especial da garantia da ordem pública e sua conformidade constitucional.

\section{A presunção de inocência, o ônus probatório no processo penal e o in dubio pro reo}

A determinação da culpabilidade somente após o trânsito em julgado da sentença penal condenatória, nos termos do artigo $5^{\circ}$, inciso LVII da CRFB, consiste em um desdobramento do princípio de submissão da jurisdição, nos moldes defendidos por Luigi Ferrajoli; se a condenação somente advém de prova inequívoca do cometimento do delito e essa apenas pode ser obtida por meio da jurisdição, correto afirmar que "não há culpa sem juízo e, em sentido estrito, que não haja juízo sem que a acusação se sujeite à prova e à refutação". 5

A presunção de inocência e seus desdobramentos não constituem novidade do ordenamento jurídico brasileiro. A Convenção dos Direitos do Homem e do Cidadão de 1789, em resposta ao sistema repressivo estatal em vigor durante o período medievo ${ }^{6}$, já dispunha sobre a inocência dos acusados da prática de crimes até que fossem considerados culpados (artigo $9^{\circ}$ ) e sobre a excepcionalidade das prisões antes do julgamento (artigo $7^{\circ}$ ); no mesmo sentido, o Pacto Internacional sobre Direitos Civis e Políticos (artigo $9^{\circ}$ ), que integra a legislação brasileira desde 1992, garante o direito à liberdade e a proteção contra o encarceramento imotivado.

Em que pese a concisão do texto da Constituição da República ao tratar da presunção de inocência, é possível identificar, a partir de uma análise mais profunda, três sentidos para esse princípio; segundo Aury Lopes Júnior, a presunção de inocência abrange uma regra de tratamento (dever de tratamento), uma regra de julgamento (dimensão interna do processo) e uma regra de garantia ${ }^{7}$.

A presunção de inocência como regra de tratamento pressupõe a forma como o réu deve ser enxergado durante o curso do procedimento penal até o trânsito em julgado da sentença condenatória, a saber, como inocente; implica dizer que não dever ser tratado de maneira estigmatizada por responder a um processo penal, tampouco deve ter sua liberdade cerceada no sentido de antecipação do cumprimento de pena ${ }^{8}$. Ainda, Aury Lopes Jr. chama a atenção da

\footnotetext{
${ }^{5}$ FERRAJOLI, op. Cit., p. 505.

${ }^{6}$ André Luiz Nicolitt, ao tratar da historicidade do princípio da presunção de inocência, apresenta um panorama do sistema processual penal em vigor na Idade Média: "na idade média, na Europa continental, a autoridade do Estado se sobrepunha à liberdade individual do cidadão. O Juiz acumulava as funções de instrução, acusação e de julgamento, ocupando uma posição de superioridade sobre o acusado, que não possuía nenhum tipo de garantia." (NICOLITT, André Luiz. Intervenções Corporais - O processo penal e as novas tecnologias: uma análise luso-brasileira. Tese (Doutorado em Direito). Universidade Católica Portuguesa. Lisboa, 2010, p. 223. Disponível em: https://repositorio.ucp.pt/handle/10400.14/4392. Acesso em 11 de junho de 2019).

${ }^{7}$ LOPES Jr, Aury. Direito Processual Penal. São Paulo: Saraiva, 2018, p. 96-97.

${ }^{8}$ NICOLITT, op. Cit., p. 227.
} 
aplicabilidade da regra de tratamento sob a perspectiva do magistrado, que deve conduzir o processo considerando o réu inocente (posição positiva) e não culpado (posição negativa) ${ }^{9}$.

Como uma regra de julgamento, a presunção de inocência enquanto dimensão interna do processo, refere-se à distribuição da carga probatória no processo penal. No sistema penal acusatório $^{10}$, vigora (ao menos em tese) o ônus probatório a cargo do órgão acusador; é por assim dizer: o acusado não precisa demonstrar sua inocência, mas a acusação precisa demonstrar a culpa do acusado para ensejar condenação. Ademais, como preceito da regra de julgamento, as garantias processuais do réu devem ser respeitadas no curso da instrução processual, inclusive o direito de não fazer prova contra $\mathrm{si}^{11}$.

A terceira dimensão do princípio da presunção de inocência encontra previsão taxativa na Constituição da República, ao tratar da proibição de utilização de provas ilícitas no processo (artigo $5^{\circ}$, inciso LIV); vale dizer que o respeito à regra de garantia pressupõe o respeito à legislação (constitucional e/ou infraconstitucional) ${ }^{12}$, tanto durante a marcha processual penal, quanto na fase pré-processual (mesmo com predominância inquisitória).

Para o objeto de estudo desse artigo, o respeito ao princípio da presunção de inocência está relacionado à possibilidade de decretação da prisão preventiva no curso do procedimento penal; conforme restará esclarecido em tópico próprio, a restrição de liberdade antes de prolação de sentença penal condenatória constitui medida excepcional, não podendo ser utilizada como forma de antecipação de cumprimento de pena, justamente em razão da observância obrigatória da determinação de culpabilidade somente após o trânsito em julgado de sentença penal condenatória.

A garantia da manutenção do estado democrático de direito perpassa, ainda, pela observância da distribuição do ônus probatório no processo penal. Assim como na regra de distribuição da carga probatória no processo civil ${ }^{13}$, no direito processual penal o ônus probatório cabe a quem acusa e decorre da função da presunção de inocência como regra de julgamento; o artigo 156 do Código de Processo Penal dispõe que a "prova da alegação incumbirá a quem a

\footnotetext{
${ }^{9}$ LOPES Jr, Aury. Direito Processual Penal e sua conformidade constitucional - Volume 1. Rio de Janeiro: Editora Lumen Juris, 2009, p. 192.

${ }^{10}$ Em linhas gerais (até por não ser o objetivo deste estudo esgotar o estudo sobre o sistema acusatório e sua real vigência do direito brasileiro), é possível afirmar que referido sistema caracteriza-se pelas separações das posições acusatória e julgadora e pela imparcialidade do juiz; nos dizeres de Claus Roxin, "coincide com el procedimiento acusatorio puro em que las atividades de persecución penal y de juzgamiento están repartidas em dos autoridades independientes (fiscalía y tribunal), em que el tribunal que conoce se mantiene apartado de todas las atividades de investigación eN el procedimento preparatório y em que la apertura de la cognición jurisdicional está condicionada al ejercicio de la acción". (ROXIN, Claus. Derecho Procesal Penal. Buenos Aires: Editores del Puerto, 2003, p. 122).

11 NICOLITT, op. Cit., p. 230.

12 NICOLITT, op. Cit., p. 231.

13 Como regra geral, o artigo 373 do Código de Processo Civil Brasileiro estabelece o ônus da prova ao autor, quanto ao fato constitutivo de seu direito e ao réu quanto à existência de fato impeditivo, modificativo ou extintivo do direito do autor.
} 
fizer"; conclui-se, então, que nas ações penais, não cumpre ao acusado demonstrar que não cometeu o delito, cumpre à acusação elidir a presunção de inocência do primeiro e, não obtendo sucesso, a absolvição do réu é medida que se impõe.

Para o efetivo afastamento do princípio da não culpabilidade, é necessário que o órgão acusador, além de observar rigorosamente a legislação processual penal, inclusive a proibição constitucional de utilização de provas ilícitas, precisa comprovar taxativamente a culpa do réu; isso significa que não bastam meros indícios de tipicidade, ilicitude e culpabilidade, é preciso que a prova da culpa seja certeira; nas palavras de Nelson Nery Júnior, "a acusação é que precisa derrubar a presunção constitucional iuris tantum que milita em favor do réu. Condenação, só com prova induvidosa da culpabilidade, prova essa cujo ônus cabe à acusação" ${ }^{14}$.

Como descrito em relação ao princípio da não culpabilidade, a distribuição do ônus da prova reflete diretamente na possibilidade de decretação da prisão preventiva no curso do procedimento penal. Ora, se cabe à acusação a incumbência de provar a culpa e a condenação, somente ocorrerá se a culpa for provada induvidosamente, é ilógico, em um primeiro momento, admitir a decretação da prisão preventiva, em virtude da incompletude da instrução processual. ${ }^{15}$

O brocardo in dubio pro reo é uma expressão originária do latim que se traduz, literalmente, como "a favor do réu" "16 é considerado um dos princípios de maior relevância para o atual sistema penal pátrio e significa que, quando o conjunto probatório colhido durante a instrução processual não for suficiente para caracterizar a tipicidade, ilicitude e culpabilidade da conduta do acusado, este deve ser absolvido, como decorrência direta da presunção de inocência, mas com esta não se confunde.

As diferenças entre a presunção de não culpabilidade e o in dubio pro reo perpassam pelo momento de aplicação de cada instituto, pela distinção das hipóteses de aplicação e pelos destinatários de cada aplicação. Enquanto que a presunção de inocência deve nortear o procedimento criminal em sua fase instrutória (e investigatória), o "a favor do réu" prevalece nos momentos de acusação e de prolação de sentença penal, quando a primeira não conseguir comprovar a culpa do acusado; a presunção de inocência é aplicada em qualquer caso e o in dubio pro reo somente nos casos de não comprovação de cometimento do delito ou de dúvidas sobre o

\footnotetext{
${ }^{14}$ NERY JÚNIOR, Nelson. Princípios do processo na Constituição Federal. São Paulo: Editora Revista dos Tribunais, 2010 , p. 305.

${ }^{15}$ Não se descuida, aqui de reconhecer a legalidade da prisão preventiva em sentido geral, pois o instituto é, inclusive, previsto pelo ordenamento jurídico brasileiro; a afirmativa refere-se ao confronto puro entre presunção de inocência, ônus da prova e prisão preventiva, sem considerar, por hora, as especificidades que autorizam a decretação da medida cautelar em comento.

16 Artigo 386, inciso VII do Código de Processo Penal.
} 
cometimento; o "a favor do réu" é destinado ao juiz no momento de sentenciar e a presunção de inocência é destinada a todo o corpo social. ${ }^{17}$

\section{Da prisão preventiva: excepcionalidade e proporcionalidade como critérios para sua decretação}

Conforme se verificou no tópico anterior, a liberdade individual é regra consolidada no texto constitucional brasileiro; a garantia da liberdade é, como visto, consequência direta dos princípios da presunção de inocência, da regra do ônus probatório no processo penal e do in dubio pro reo. Todavia, o artigo $5^{\circ}$, inciso LXI do texto constitucional admite a mitigação dos princípios acima citados em situações excepcionais, como, por exemplo, a permissão para decretação da prisão preventiva nos termos do artigo 312 do Código de Processo Penal.

A prisão preventiva é uma modalidade de prisão cautelar; por cautelar, em termos processuais gerais, entende-se a medida judicial necessária para garantir a normalidade do andamento do processo, sendo uma medida que nada tem a ver com mérito da ação, mas somente com a conservação do direito disputado até o final do procedimento ${ }^{18}$; pode ser decretada tanto durante a fase de inquérito policial quanto durante a fase processual criminal ${ }^{19}$. A disciplina da prisão preventiva situa-se no Capítulo III do CPP; para esse trabalho, especial interesse desperta o conteúdo do artigo 312, caput.

Art. 312. A prisão preventiva poderá ser decretada como garantia da ordem pública, da ordem econômica, por conveniência da instrução criminal, ou para assegurar a aplicação da lei penal, quando houver prova da existência do crime e indício suficiente de autoria.

A prisão preventiva não é custódia a ser utilizada como regra; a sua aplicação deve observar a excepcionalidade da medida e a proporcionalidade da aplicação ao caso concreto, ficar adstrita à presença das situações previstas no caput do artigo 312 da lei processual penal e ser devidamente fundamentada, sob pena de nulidade. Analisar-se-á, agora, os critérios de excepcionalidade e de proporcionalidade para decretação da prisão preventiva.

A excepcionalidade da prisão preventiva está diretamente relacionada com o princípio da presunção de inocência; se a regra prevalecente no sistema processual penal brasileiro é a de que um acusado somente poderá ser considerado culpado após o trânsito em julgado de eventual sentença condenatória, não há motivo para que tenha sua liberdade tolhida antes da referida

\footnotetext{
${ }_{17}$ NICOLITT, op. Cit., p. 233.

18 MONTENEGRO Filho, Misael. Curso de Direito Processual Civil - Medidas de urgência, tutela antecipada, ação cautelar e procedimentos especiais. São Paulo: Atlas, 2010, p. 48.

${ }^{19}$ ROXIN, op. Cit., p. 259.
} 
sentença. Ocorre que o ordenamento jurídico pátrio acolheu a possibilidade de custódias cautelares, sendo necessário, então, harmonizá-las com a não culpabilidade; essa harmonização é materializada com a aplicação do critério de excepcionalidade da privação de liberdade ${ }^{20}$ e encontra amparo no próprio artigo 312 do CPP: quando houver prova da existência do crime e indício suficiente de autoria, ou seja, na presença do fumus commissi delicti e do periculum libertatis.

O fumus commissi delicti exige a demonstração taxativa de prova da existência do crime e de indícios suficientes de autoria; não se deve exigir a certeza desses dois elementos, pois isso somente poderá ocorrer ao término da instrução processual, mas é preciso que o juiz indique com o máximo de clareza a presença de fatos aptos a demonstrar que o delito efetivamente ocorreu e que o acusado pode ser o autor do fato; "achismos", conjecturas, não são suficientes para caracterização do fumus commissi delicti. Nas palavras de Maurício Zanóide de Moraes,

\begin{abstract}
pela previsão do "fumus delicti commissi" o legislador exigirá que o juiz demonstre, de modo objetivo e concreto, quais são os elementos constantes dos autos (investigativos ou judiciais) reveladores da existência de crime (materialidade) e em que medida o imputado a ser submetido à coação está envolvido com os fatos (autoria). Determinará também que o grau de convicção judicial seja tão mais elevado quanto mais restritiva for a medida a ser aplicada. O julgador deverá indicar sempre de quais elementos objetivos e constantes dos autos extraiu a base fática para formar sua convicção de que o crime ocorreu e que o sujeito a ser submetido à constrição está envolvido em seu cometimento $^{21}$
\end{abstract}

O periculum libertatis é semelhante a uma segunda fase do critério da excepcionalidade e somente será analisado se houver comprovação da primeira fase (que seria o fumus commissi delicti). Por periculum libertatis, compreende-se que, caso mantida a liberdade do acusado, este ofenderia a ordem pública, a ordem econômica, a conveniência da instrução criminal, ou apresentaria óbice aplicação da lei penal2 ${ }^{22}$; assim como para a demonstração do fumus commissi delicti, para a demonstração do periculum libertatis não bastam "achismos" e conjecturas; é necessário que o juiz indique com o máximo de clareza a presença desses elementos no caso concreto.

O critério da proporcionalidade não é exclusivo do sistema processual penal, mas norteador de todo o sistema jurídico brasileiro e corresponde à necessidade de aplicação do direito de forma igualitária e menos onerosa para a sociedade. Para Carlos Roberto Siqueira Castro, "a ideia (ou ideário) da proporcionalidade persegue, assim, a justa e equânime distribuição

\footnotetext{
${ }^{20}$ MORAES. Maurício Zanóide de. Presunção de inocência no processo penal brasileiro: análise de sua estrutura normativa para a elaboração legislativa e para a decisão judicial. Rio de Janeiro: Editora Lumen Juris, 2010, s.p. E-book. Disponível em: https://www.zmpbc.com.br/gerenciador/arquivos/1/mzm-tese-de-livre-docencia.pdf. Acesso em 11 de junho de 2019.

${ }^{21}$ MORAES, op. Cit., s.p.

22 LOPES Jr., op. Cit., p. 636-637.
} 
de ônus e encargos, e também de bônus e vantagens, nos incontáveis contextos de disputas, litígios e concorrências intersubjetivas" 23 .

No âmbito do direito processual penal e, mais especificamente, como critério norteador para decretação da prisão preventiva, a proporcionalidade refere-se a real necessidade de decretação dessa custódia cautelar, ou seja, deve-se observar se a decretação da prisão preventiva não se mostra excessiva no caso concreto ${ }^{24}$. Para exemplificar, observa-se os casos de supostos delitos cuja pena máxima não enseje a privação de liberdade; nesses casos, não é proporcional a decretação da prisão preventiva, haja vista que a restrição de liberdade não se confirmará ao final do processo $^{25}$.

Analisados os critérios de excepcionalidade e proporcionalidade para decretação da prisão preventiva, faz-se necessário discorrer acerca dos desdobramentos do periculum libertatis, especificamente aquele fundado na garantia da ordem pública, objeto de investigação dessa pesquisa.

\section{Da análise constitucional dos decretos de prisões preventivas fundados exclusivamente na garantia da ordem pública}

Como já exposto, por periculum libertatis, compreende-se que, caso mantida a liberdade do acusado, este ofenderia a ordem pública, a ordem econômica, a conveniência da instrução criminal, ou apresentaria óbice aplicação da lei penal ${ }^{26}$. Interessa, para esse artigo, refletir apenas sobre o periculum libertatis fundado na garantia da ordem pública, conceito amplo, sem definição precisa e de difícil delimitação.

A atual Constituição brasileira, em que pese mencionar a "ordem pública" em alguns de seus artigos (artigo 34, inciso III; artigo 136, caput, artigo 144, caput e parágrafos $5^{\circ}$ e 10), não traz em seu texto uma definição clara para a expressão; da mesma forma, a lei processual penal brasileira vigente somente cita a garantia da ordem pública em seus dispositivos, sem dedicar maiores esforços na definição da locução.

No âmbito de atuação do Supremo Tribunal Federal, o conceito de ordem pública também é indefinido. Em algumas decisões, é possível encontrar os termos clamor público, gravidade do delito, credibilidade das instituições e risco de reiteração da prática de condutas

\footnotetext{
${ }^{23}$ CASTRO, Carlos Roberto Siquera. O devido processo legal e os princípios da razoabilidade e da proporcionalidade. Rio de Janeiro: Editora Forense, 2005, p. 199-200.

${ }^{24}$ Sobre o critério da proporcionalidade para decretação das prisões preventivas, vale destacar a lição de Claus Roxin: "el principio constitucional de proporcionalidade exige restringir la medida y los limites de la prisión preventiva a lo estrictamente necessário" (ROXIN, op. Cit., p. 258).

${ }^{25}$ LOPES Jr., Aury. Direito processual penal e sua conformidade constitucional - Volume II. Rio de Janeiro: Editora Lúmen Júris, 2011, p. 74.

${ }^{26}$ LOPES Jr., op. Cit., p. 636-637.
} 
criminosas como fundamentos da garantia da ordem pública, contudo, o entendimento da suprema corte em relação à essas definições ainda é diverso e carece de pacificação. ${ }^{27}$

Por clamor público, entende-se o abalo psicológico sofrido pela população do local de cometimento do suposto delito em razão deste; prende-se preventivamente, portanto, quando o hipotético crime perturba a tranquilidade $\operatorname{social}^{28}$ ou quando provoca intensa repercussão midiática. Nesse ponto, é preciso tecer breves considerações sobre o posicionamento do Supremo Tribunal Federal no que tange a pertinência do clamor público como autorizador do decreto preventivo.

Como guardião do texto constitucional, cabe ao Supremo Tribunal Federal velar pela garantia dos direitos fundamentais; essa garantia compreende a limitação do poder público e a proteção contra tentativas de supressão de direitos pautadas na vontade de massa ${ }^{29}$, consistindo em verdadeiros trunfos contra a maioria; significa dizer que os direitos fundamentais asseguram "a existência de posição juridicamente garantida contra as decisões políticas de eventuais maiorias política" ${ }^{30}$.

Pode-se afirmar, então, que não deve o STF, ao prolatar uma decisão, fazê-lo utilizando como fundamento "o clamor público", a repercussão midiática, especialmente quando essas manifestações pleiteiam ofensa ao texto constitucional e aos direitos fundamentais, como a liberdade de ir e $\operatorname{vir}^{31}$.

Seguindo esse raciocínio, o STF, ao analisar a manutenção de decretos de prisões preventivas baseadas no clamor público, tem decidido por sua inadmissibilidade, justamente por ser elemento confrontante com a garantia dos direitos fundamentais e incompatível com o objetivo estritamente processual da medida; é o que se infere, por exemplo, dos Habeas Corpus 115.897/2013-PR e 80.719/2001-SP, no qual o Ministro Celso de Mello deixa clara a incongruência entre o clamor público e o texto constitucional:

O estado de comoção social e de eventual indignação popular, motivado pela repercussão da prática da infração penal, não pode justificar, só por si, a decretação da prisão cautelar do suposto autor do comportamento delituoso, sob pena de completa e grave aniquilação do postulado fundamental da liberdade. O clamor público -

27 Cita-se, como exemplo, o Habeas Corpus 135.250/2016, de relatoria do Ministro Teori Zavascki; o Habeas Corpus 117.876 AgR/SC/2013, de relatoria do Ministro Luiz Fux e o Habeas Corpus 111.244/SP/2012, de relatoria do Ministro Ayres Britto.

${ }^{28}$ NUCCI, Guilherme de Souza. Manual de Processo Penal e Execução Penal. E-book. Rio de Janeiro: Editora Forense, 2016, s.p.

${ }^{29}$ ABBOUD, 2012, p. 3.

30 ABBOUD, 2012, p. 03.

31 Nesse sentido, a manifestação do Ministro do STF, Celso de Mello: "a prerrogativa jurídica da liberdade - que possui extração constitucional (CF, art. 5 $5^{\circ}$ LXI e LXV) - não pode ser ofendida por interpretações doutrinárias ou jurisprudenciais, que, fundadas em preocupante discurso de conteúdo autoritário, culminam por consagrar, paradoxalmente, em detrimento de direitos e garantias fundamentais proclamados pela Constituição da República, a ideologia da lei e da ordem" (HC 80.719/2001-SP). 
precisamente por não constituir causa legal de justificação da prisão processual (CPP, art. 312) - não se qualifica como fator de legitimação da privação cautelar da liberdade do indiciado ou do réu.

Entretanto, a rejeição ao argumento do clamor público como fundamento do decreto de prisão preventiva é controverso no STF; em alguns julgamentos, como no referente ao Habeas Corpus 85.3625/2005-MA, de relatoria do Ministro Gilmar Mendes, a Segunda Turma entendeu ser o clamor público, suficientemente demonstrado, argumento válido para decretação da referida custódia cautelar; no mesmo sentido, cita-se o HC 117.876/2013- AgR/SC, de relatoria do Ministro Luiz Fux.

A alegação de conservação da credibilidade das instituições para decretação da custódia cautelar funda-se na crença de que ao Poder Judiciário cabe o dever de prender acusados da prática de crimes para que reste comprovada credibilidade e seu "respeito às leis"; nas palavras de Aury Lopes Jr., “é prender para reafirmar a 'crença' no aparelho estatal repressor" ${ }^{\text {”2 }}$, passando falsa sensação de segurança à população.

O risco de reiteração da prática de condutas criminosas é verdadeira utilização da prisão preventiva como medida de segurança pública ${ }^{33}$; prende-se o réu, pois este, em liberdade, poderá praticar novos crimes e abalar, novamente, a ordem pública; mesmo com a obrigatoriedade de fundamentação e demonstração de seus requisitos de forma robusta para a decretação da custódia cautelar, a garantia da ordem pública em razão de suposta reiteração criminosa funda-se apenas em uma probabilidade, que não tem como ser científica ou faticamente demonstrada. Ademais, “o risco de repetição e o risco de desordem pública somente servem a interesses de prevenção geral do crime, não ao próprio processo. Consequentemente a prisão preventiva baseada nesses motivos é considerada como uma medida punitiva" ${ }^{34}$ e, portanto, em desconformidade com os ditames constitucionais.

Sobre os argumentos para decretação da prisão preventiva fundada na garantia da ordem pública, oportuno transcrever a reflexão de Luigi Ferrajoli, que caracteriza a medida, nos termos hoje em voga, como policialesca:

O traço inconfundivelmente policialesco do instituto - que foi demonstrado no parágrafo 38, com a incompatibilidade em relação a todas as garantias penais e processuais, e antes de toda a presunção de não culpabilidade - resta no caráter arbitrário, em todos os casos não cognitivo, mas potestativo dos seus pressupostos. Pela sua natureza, de fato, não são passíveis de provas ou desmentidos nem "a gravidade" dos indícios de culpabilidade, tampouco as razões opinativas que possam fazer supor o "perigo" de fuga, ou de turvação de prova ou de futuros delitos por parte do imputado. Este último motivo de captura, em particular, é irremediavelmente

\footnotetext{
${ }^{32}$ LOPES Jr., op. Cit., p. 637.

${ }^{33}$ LOPES Jr., op. Cit., p. 650.

${ }^{34}$ SANGUINÉ, 2014, p. 299.
} 
policialesco e revela o caráter da medida de prevenção e de defesa social verdadeiramente assumido pela custódia cautelar. ${ }^{35}$

Apresentados os principais aspectos do critério de garantia da ordem pública, resta refletir acerca da possível inconstitucionalidade dos decretos de prisão preventiva fundados na garantia nesse critério, considerando-se que fere os princípios da presunção de inocência, da distribuição do ônus da prova do processo penal e do in dubio pro reo.

Conforme já verificado, o sistema processual penal brasileiro, em relação ao acusado, tem como princípios norteadores, dentre outros, a presunção de inocência, a distribuição do ônus probatório e o in dubio pro reo. A legislação pátria, todavia, prevê a mitigação desses princípios ao autorizar a decretação da prisão preventiva ainda no curso do procedimento investigatório ou processual; essa mitigação deve atender a uma série de critérios rigorosos, ser devidamente fundamentada em provas robustas e observar a excepcionalidade e a proporcionalidade no caso concreto, sendo defesa à autoridade judiciária a decretação dessa custódia cautelar de maneira arbitrária e vaga.

Não se discutiram, aqui, todos os motivos ensejadores da prisão preventiva, limitando-se à garantia da ordem pública e suas possíveis definições, das quais é que se infere a possível inconstitucionalidade dos decretos fundamentados na garantia da ordem pública, pois esta apresenta, conforme se verá a seguir, inconsistências que impedem sua conformidade com o texto constitucional.

Primeiramente, a própria indeterminação da definição do termo “ordem pública", se analisada à luz de uma interpretação conforme a Constituição ${ }^{36}$, não se mostra compatível com o atual paradigma de estado democrático de direito, que coíbe a edição de leis com sentido obscuro e/ou incerto, em especial aquelas voltadas à limitação das liberdades individuais dos cidadãos.

Assim, não há que se falar em constitucionalidade dos decretos de prisão preventiva fundados exclusivamente na garantia da ordem pública, sem antes, ao menos, se delimitar/esclarecer o sentido do vocábulo. Autorizar a custódia cautelar preventiva com fundamento em uma expressão que pode significar qualquer coisa (ou até mesmo coisa nenhuma) a depender da interpretação utilizada pelo julgador, é punir de forma arbitrária o direito fundamental à liberdade; nas palavras de Odone Sanguiné,

A indeterminação do conceito de ordem pública possibilita - na esteira do espírito autoritário do CPP vigente, editado sob a atmosfera fascista do Estado Novo com

35 FERRAJOLI, op. Cit., p. 716.

${ }^{36}$ A interpretação conforme a Constituição, suscintamente, é aquela em que o julgador, diante de duas interpretações possíveis para uma norma, utiliza aquela que se mostra compatível com o texto constitucional; é, como leciona Lênio Streck, "um princípio imanente da Constituição, até porque não há nada mais imanente a uma Constituição do que a obrigação de que todos os textos normativos do sistema sejam interpretados de acordo com ela”. (STRECK, 2002 p. 443) 
inspiração no Código Italiano de Mussolini - o arbítrio nos decretos de prisão preventiva, especialmente contra aqueles acusados desprovidos de recursos, materiais e culturais, submetendo-os à repressão penal autoritária e discriminatória. ${ }^{37}$

Ademais, é preciso apontar a característica cautelar da prisão preventiva e a não correspondência da cautelaridade no que tange à garantia da ordem pública. A prisão cautelar destina-se a garantir a normalidade da marcha processual penal, sendo uma medida que nada tem a ver com mérito da ação; desta feita, ilógico admitir a prisão preventiva fundada no clamor público, na gravidade do delito, na preservação da credibilidade das instituições e no risco de reiteração da prática de condutas criminosas, pois nenhuma dessas justificativas conserva o caráter cautelar da prisão ${ }^{38}$.

O clamor público, cuja incidência se dá quando o hipotético crime perturba a tranquilidade social, não guarda nenhuma similaridade com o caráter cautelar da prisão preventiva; da mesma forma, a gravidade do delito, que somente será analisada ao final da instrução processual, quando da prolação da sentença; a credibilidade das instituições demonstra, ainda, maior grau de incompatibilidade com a cautelaridade da prisão, pois não é função do Poder Judiciário prender preventivamente os acusados da prática de crimes para passar à população uma sensação de segurança ${ }^{39}$; por fim, ilógico admitir a decretação da prisão preventiva em razão de suposta reiteração criminosa, pois constitui ofensa direta ao princípio da presunção de inocência ${ }^{40}$.

Dessa reflexão, infere-se que, nos casos acima apresentados, a prisão preventiva constitui verdadeira antecipação de pena; nas palavras de Luigi Ferrajoli, "primeiro se pune e, depois, se processa, ou melhor, se pune processando" ${ }^{41}$, em verdadeira afronta ao texto constitucional que consagrou a presunção de inocência. Ademais, constituindo antecipação de pena, a custódia cautelar coloca em xeque o papel do próprio direito processual penal: o objetivo do processo penal é apurar o cometimento do delito e, restando comprovado, aplicar sanção; como a prisão preventiva fundada exclusivamente na garantia da ordem pública antecipa o cumprimento de pena, o processo penal perde sua razão de $\operatorname{ser}^{42}$.

\footnotetext{
37 SANGUINÉ, 2014, p. 296.

38 Sobre a cautelaridade da prisão preventiva, destaca-se a lição de Roberto Delmanto Júnior: “toda custódia imposta durante a persecução penal há que ser determinada, única e exclusivamente, em função da necessidade de tutela do bom andamento do processo penal (incluindo, aqui, o inquérito policial) e da garantia da eficácia de eventual condenação (necessidade cautelar: instrumental e final)”. (DELMANTO JR., Roberto. DELMANTO. Fábio Machado de Almeida. A dignidade da pessoa bumana e o tratamento dispensado aos acusados no Processo Penal. Revista dos Tribunais: RT, v. 4, $\mathrm{n}^{\mathrm{o}} 835$, p. 443-466, maio 2005, p. 460. Disponível em: http://www.delmanto.com/Conteudo/artigos/2005/Roberto $\% 20 \mathrm{Jr} \% 20 \mathrm{e} \% 20 \mathrm{Fabio} / \mathrm{a}$ dignidade da pessoa huma na.pdf. Acesso em 11 de junho de 2019).

39 DELMANTO Jr., op. Cit., p. 461.

40 DELMANTO Jr., op. Cit., p. 466.

${ }^{41}$ FERRAJOLI, op. Cit., p. 716.

42 DELMANTO Jr., op. Cit., p. 466.
} 


\section{Considerações finais}

O ordenamento jurídico brasileiro, ao tratar do seu sistema processual penal, prevê normas garantidoras da liberdade e da dignidade dos acusados pela prática de delitos, a fim de que seja resguardada a manutenção do estado democrático de direito no sentido de garantia das prerrogativas fundamentais do indivíduo; para tanto, considera, dentre outras normas, a presunção de inocência, a distribuição do ônus da prova e o in dubio pro reo. Essas garantias somente podem ser mitigadas em situações excepcionais, devidamente previstas em lei taxativa e mediante fundamentação robusta e livre de "achismos" e conjecturas dos magistrados.

Uma das formas de mitigação dos preceitos mencionados acima é a prisão preventiva, modalidade de custódia cautelar que tem por principal objetivo (ao menos em tese), garantir a normalidade da marcha processual penal até a prolação da sentença. A prisão preventiva encontra previsão no artigo 312 do Código Penal, que determina em quais situações é possível o seu decreto. O presente estudo analisou o critério de garantia da ordem pública como fundamento da restrição preventiva de liberdade.

Verificou-se que a garantia da ordem pública, além de ser expressão carente de definição objetiva, não se presta a acautelar o processo penal quando utilizada para justificar o clamor público, a gravidade do delito, a credibilidade das instituições e o risco de reiteração da prática de condutas criminosas.

Primeiro, sublinha-se que o caráter genérico do termo "ordem pública", além de gerar insegurança jurídica, não se mostra compatível com o atual paradigma de estado democrático de direito, que coíbe a edição de leis com sentido obscuro e/ou incerto, em especial aquelas voltadas à limitação das liberdades individuais dos cidadãos.

Segundo, verificou-se que as expressões clamor público, gravidade do delito, credibilidade das instituições e risco de reiteração da prática de condutas criminosas, embora apareçam em várias decisões do Supremo Tribunal Federal como sinônimos de "ordem pública", não são suficientes para ensejar um decreto de custódia cautelar preventiva, consistindo suas utilizações, na verdade, em prisão revestida de caráter de antecipação de pena, o que enseja, ainda, o perecimento da razão de ser do processo penal.

Por esses motivos e com esteio na vasta posição doutrinária apresentada nesse trabalho, como, por exemplo, Aury Lopes Jr. Luigi Ferrajoli, Roberto Delmanto, André Luiz Nicolitt e Maurício Zanóide de Moraes, conclui-se que, em uma interpretação conforme a Constituição, os decretos de prisão preventiva fundados exclusivamente na garantia da ordem pública, quando utilizada para justificar os critérios no mínimo incertos e indefinidos consoante mencionado no 
presente estudo, são revestidos de inconstitucionalidade, pois, não revestidos de excepcionalidade e proporcionalidade, não encontram-se em conformidade aos princípios da não culpabilidade, da distribuição do ônus da prova no processo penal e do in dubio pro reo.

\section{Referências}

ABBOUD, Georges. STF vs. vontade da maioria: razões pelas quais a existência do STF somente se justifica se ele for contramajoritário. Revista dos Tribunais, ano 101, v. 921, jul. 2012. Disponível em: http://sentidounico.com.br/wp-content/uploads/2017/09/Georges-Abboud-STF-VSVONTADE-DA-MAIORIA-AS-RAZ $\%$ C $3 \% 95$ ES-PELAS-QUAIS-A-EXIST $\%$ C3\%8ANCIADO-STF-SOMENTE-SE-JUSTIFICA-SE-ELE-FOR-CONTRAMAJORIT\%C3\%81RIO.pdf. Acesso em 14 dez. 2019.

BRASIL. Código de Processo Civil. Disponível em: http://www.planalto.gov.br/ccivil 03/ ato20152018/2015/lei/113105.htm. Acesso em: 11 jun. 2019.

BRASIL. Código de Processo Penal. Disponível em: http://www.planalto.gov.br/ccivil 03/decretolei/del3689compilado.htm. Acesso em: 11 jun. 2019.

BRASIL. Constituição da República Federativa do Brasil de 1988. Disponível em: http://www.planalto.gov.br/ccivil 03/constituicao/constituicao.htm. Acesso em: 11 jun. 2019.

BRASIL. HC 111.244/SP. Relator(a): Ayres Britto. Julgamento: 10/04/2012. Órgão Julgador: Segunda Turma. Dje 26/06/2012. Disponível em:

http://redir.stf.jus.br/paginadorpub/paginador.jsp?docTP=TP\&docID=2218377. Acesso em 23 jun. 2020.

BRASIL. HC 115.897/PR. Relator(a): Min. Marco Aurélio. Julgamento: 04/06/2013. Órgão Julgador: Primeira Turma. Dje 24/06/2013. Disponível em:

http://redir.stf.jus.br/paginadorpub/paginador.jsp?docTP=TP\&docID=4067385. Acesso em 24 jun. 2020.

BRASIL. HC 117.876 AgR/SC. Relator(a): Min. Luiz Fux. Julgamento: 08.10.2013. Órgão Julgador: Primeira Turma. Dje 23.10.2013. Disponível em: http://redir.stf.jus.br/paginadorpub/paginador.jsp?docTP=TP\&docID=4743397. Acesso em 24 jun. 2020.

BRASIL. HC 135.250/SP. Relator(a): Teori Zavascki. Julgamento: 13/09/2016. Órgão julgador: Segunda Turma. Dje 28-09-2016. Disponível em:

http://redir.stf.jus.br/paginadorpub/paginador.jsp?docTP $=T P \& d o c I D=11744823$. Acesso em 24 jun. 2020.

BRASIL. HC 80.719/SP. Relator(a): Min. Celso de Mello. Julgamento: 26/06/2001. Órgão Julgador: Segunda Turma. DJ 28/09/2001. Disponível em: http://redir.stf.jus.br/paginadorpub/paginador.jsp?docTP=AC\&docID=78493. Acesso em 24 jun. 2020.

BRASIL. HC 85.3625/MA. Relator(a): Min. Gilmar Mendes. Julgamento: 31/05/2005. Órgão Julgador: Segunda Turma. Dje 22/11/2007. Disponível em: 
http://redir.stf.jus.br/paginadorpub/paginador.jsp?docTP=AC\&docID=495538. Acesso em 24 de jun. 2020.

BRASIL. Pacto internacional sobre direitos civis e politicos. Disponível em: http://www.planalto.gov.br/ccivil 03/decreto/1990-1994/d0592.htm. Acesso em: 11 jun. 2019.

CASTRO, Carlos Roberto Siquera. O devido processo legal e os principios da razoabilidade e da proporcionalidade. Rio de Janeiro: Editora Forense, 2005.

DECLARAÇÃO UNIVERSAL DOS DIREITOS DO HOMEM E DO CIDADÃO DE 1789. Disponível em: http://www.direitoshumanos.usp.br/index.php/Documentos-anteriores$\% \mathrm{C} 3 \% \mathrm{~A} 0$-cria $\% \mathrm{C} 3 \% \mathrm{~A} 7 \% \mathrm{C} 3 \% \mathrm{~A} 3 \mathrm{o}-\mathrm{da}-S o c i e d a d e-d a s-\mathrm{Na} \% \mathrm{C} 3 \% \mathrm{~A} 7 \% \mathrm{C} 3 \% \mathrm{~B} 5 \mathrm{es}-\mathrm{at} \% \mathrm{C} 3 \% \mathrm{~A} 9-$ 1919/declaracao-de-direitos-do-homem-e-do-cidadao-1789.html. Acesso em: 11 jun. 2019.

DELMANTO Jr., Roberto. DELMANTO. Fábio Machado de Almeida. A dignidade da pessoa humana e o tratamento dispensado aos acusados no processo penal. Revista dos Tribunais: RT, v. 4, $n^{\circ}$ 835, mai. 2005. Disponível em:

http://www.delmanto.com/Conteudo/artigos/2005/Roberto $\% 20 \mathrm{Jr} \% 20 \mathrm{e} \% 20 \mathrm{Fabio} / \mathrm{a}$ dignidad e da pessoa humana.pdf. Acesso em 11 jun. 2019.

FERRAJOLI, Luigi. Direito e razãa: teoria do garantismo penal. São Paulo: Editora Revista dos Tribunais, 2010.

LOPES Jr., Aury. Direito processual penal e sua conformidade constitucional - volume I. Rio de Janeiro: Editora Lúmen Juris, 2009.

LOPES Jr., Aury. Direito processual penal e sua conformidade constitucional - volume II. Rio de Janeiro: Editora Lúmen Júris, 2011.

LOPES Jr., Aury. Direito processual penal. São Paulo: Saraiva, 2018.

MONTENEGRO Filho, Misael. Curso de direito processual civil: medidas de urgência, tutela antecipada, ação cautelar e procedimentos especiais. São Paulo: Atlas, 2010.

MORAES, Maurício Zanóide de. Presunção de inocência no processo penal brasileiro: análise de sua estrutura normativa para a elaboração legislativa e para a decisão judicial. Rio de Janeiro: Editora Lúmen Juris, 2010. E-book. Disponível em:

https://www.zmpbc.com.br/gerenciador/arquivos/1/mzm-tese-de-livre-docencia.pdf. Acesso em: 11 jun. 2019.

NERY JÚNIOR, Nelson. Princípios do processo na Constituição Federal. São Paulo: Editora Revista dos Tribunais, 2010.

NICOLITT, André Luiz. Intervenções Corporais: o processo penal e as novas tecnologias: uma análise luso-brasileira. Tese (Doutorado em Direito). Universidade Católica Portuguesa. Lisboa, 2010. Disponível em: https://repositorio.ucp.pt/handle/10400.14/4392. Acesso em 11 jun. 2019.

NUCCI, Guilherme de Souza. Manual de processo penal e execução penal. E-book. Rio de Janeiro: Editora Forense, 2016, s.p. 
ROXIN, Claus. Derecho procesal penal. Buenos Aires: Editores del Puerto, 2003.

STRECK, Lênio Luiz. Jurisdição Constitucional e Hermenêutica. Uma Nova Crítica do Direito. Porto Alegre: Livraria do Advogado. 2002

VOLPATO, E. C. F. Metodologia da pesquisa versus pesquisa da metodologia: interfaces da dogmática jurídica na pós-graduação. Revista Brasileira de Pós-Graduação, v. 14, 30 out. 2017. Disponível em: http://ojs.rbpg.capes.gov.br/index.php/rbpg/article/view/1413. Acesso em 22 jun. 2020. 